\title{
Enhancing Bioethanol Production from Sugarcane Molasses by Saccharomyces cerevisiae Y17
}

\author{
Abdel-Hamied M. Rasmey ${ }^{(1) \#}$, Heba Hawary ${ }^{(1)}$, Omar A. Abdul Wahid ${ }^{(2)}$ and \\ Akram A. Abo-Seidah ${ }^{(1)}$ \\ ${ }^{(1)}$ Botany \& Microbiology Department, Faculty of Science, Suez University, Suez; \\ ${ }^{(2)}$ Botany Department, Faculty of Science, Suez Canal University, Ismailia, Egypt.
}

\begin{abstract}
7 HIS STUDY aims to investigate the recycling of agro-industrial wastes as sugarcane and beet molasses for ethanol production using many yeast isolates. Out of fifteen tested isolates of yeasts, seven isolates showed high ethanol production contributing more than or equal $7 \%$ from sugarcane molasses with productivity ranging between 1.45 and $1.78 \mathrm{gL}^{-1} \mathrm{~h}^{-1}$. Interestingly, isolate Y17 was the highest ethanol producer (8.55\%) and it was chosen for the further optimization experiments. Isolate Y17 was identified phenotypically and genotypically as Saccharomyces cerevisiae and then was deposited in the GenBank with accession number KP096551. There was a significant enhancement in the ethanol production (9.55\%) using $S$. cerevisiae $\mathrm{Y} 17$ from sugarcane molasses fermentation at $18 \%$ sugar, $30^{\circ} \mathrm{C}$ and $\mathrm{pH} 4.5$ for $96 \mathrm{~h}$ incubation period. These results suggest that Saccharomyces cerevisiae Y17 may be subjected to genetic engineering improvement and used as a promising candidate for economical ethanol fermentation by utilization of sugarcane molasses as a renewable and low cost-effective substrate.
\end{abstract}

Keyword: Bioethanol, molasses, Fermentation, Genotypic, Saccharomyces, 18S rRNA gene sequence.

\section{Introduction}

Bioethanol is considered a promising type of biofuel that produced by fermentation of sugars and used as a partial gasoline replacement in different areas of the world (Sunggyu \& Shah, 2012; Bhatia et al., 2012; Sadik \& Halema, 2014 and Rasmey et al., 2017). The sugarcane and beet molasses are by-products of sugar industries in Egypt and are cheap raw materials, readily available, and ready for conversion with limited pretreatments as compared with starchy or cellulosic materials for bioethanol fermentation on industrial scale. Most of sugars in molasses are present in a readily fermentable form (Razmovski \& Vucurovi, 2011). Sugarcane molasses is a dark viscous fluid, and rich in nutrients required by most microorganisms such as carbon, nitrogen, phosphorus, sodium, potassium and non-nitrogenous compounds. Beet molasses also is a commonly used feedstock (Dodić et al., 2009). One metric ton of sugarcane is capable of producing approximately $106 \mathrm{~kg}$ of sugar and $46 \mathrm{~kg}$ of molasses. A typical molasses to ethanol conversion rate is $4 \mathrm{~kg}$ of molasses/ $\mathrm{L}$ ethanol (Lavarack, 2001). However, this rate can vary based on production practices and sugar content of the molasses (Nguyen et al., 2009 and Silalertruksa \& Gheewala, 2010).

Molasses composition is usually influenced by the variety and maturity of the cane and beet, soil, climate and the processing conditions in the factory (El-Gendy et al., 2013). High yielding and efficient fermentation of molasses with varying composition requires selection of special yeast strains having high tolerances to inhibitory conditions as well as ability of fast fermentation. Other natural requirements like tolerance to high alcohol, sugar and temperature are also necessary (Bazmi et al., 2007)

Several microorganisms (bacteria and fungi)

\#Corresponding author email: am_rasmey@yahoo.com DOI: $10.21608 /$ ejbo. 2018.1820 .1126

Edited by: Prof. Dr. Mady A Ismail, Faculty of Science, Assiut University, Assiut, Egypt. C2018 National Information and Documentation Centre (NIDOC) 
are ethanologenic microbes. Despite the evolving trend of using bacteria for ethanol production, yeast is still the primary choice for fermentation (Chandra \& Panchal, 2003). Yeast is extensively used and well-liked microorganisms for wine and fuel ethanol fermentations due to their various unique characteristics like high growth rates (anaerobically or aerobically), proficient ethanol fermentation, and capability to tolerate various stresses (Piskur et al., 2006). Saccharomyces cerevisiae is one of the well-known ethanol producers (Izmirlioglu \& Demirci, 2012).

The main goal of the present work was to maximize bioethanol production from sugarcane molasses in batch fermentation process using Saccharomyces cerevisiae Y17.

\section{Materials and Methods}

\section{Feedstock and chemical analysis}

Five kilograms of sugarcane molasses was purchased from Sugars and Integrated Industries Egyptian Distillation Plants in Hawamdeia City, Giza, Egypt, while five kilograms of beet molasses was purchased from Delta Sugar Company (DSC), Kafr El-Sheikh, Egypt. The molasses was transferred to the laboratory into sterilized plastic bottles and stored at $4^{\circ} \mathrm{C}$.

The chemical properties of the sugarcane (ElSamman, 2010) and beet molasses (El-Tantawy, 2012) used in this study are shown in Table 1.

\section{Culture medium}

The yeast extract peptone dextrose agar (YPDA) medium of the following composition (g/L dist. $\mathrm{H}_{2} \mathrm{O}$ ): Yeast extract, 10.0; peptone, 20.0; dextrose, 20.0 and agar-agar, 20.0 had been used for maintenance and inoculum preparation according to Wickerham (1951).

\section{Yeast isolates and inocula preparation}

Fifteen yeast isolates, previously isolated from different substrates and examined for ethanol production (Hawary, 2014), were used in this study. Active cultures for fermentation experiments were prepared by growing the tested yeast isolates on YPD broth medium for $24 \mathrm{~h}$ at $30^{\circ} \mathrm{C}$ and $150 \mathrm{rpm}$.

\section{Sugarcane and beet molasses pretreatment}

The clarification of molasses was conducted according to Shashank (1994). The molasses were diluted using distilled water to prepare molasses with $18 \%$ sugar concentration and the $\mathrm{pH}$ of the diluted molasses was adjusted to 4.5 using concentrated sulfuric acid. The molasses is heated to about $95^{\circ} \mathrm{C}$ in water bath for $15 \mathrm{~min}$. The hot diluted molasses was left to settle for $2 \mathrm{~h}$ to precipitate the sludge and the cleared supernatant was transferred into the fermentation bottles.

\section{Fermentation of molasses}

Twenty four hours old yeast inoculum was used to inoculate the pretreated molasses at the rate of $10 \%$. Production of ethanol was conducted in $100 \mathrm{ml}$ glass bottles that included $45 \mathrm{ml}$ of pretreated molasses and $5 \mathrm{ml}$ of $24 \mathrm{~h}$ old culture. The bottles were incubated on a rotary shaker (150rpm) at $30^{\circ} \mathrm{C}$ for $5 \mathrm{~h}$ at aerobic conditions and continued the fermentation period to $48 \mathrm{~h}$ under anaerobic conditions by replacing the cotton plaque by rubber cover according to Gurav \& Geeta (2007).

\section{Ethanol determination}

Ethanol produced in the fermentation medium was estimated by potassium dichromate $\left(\mathrm{K}_{2} \mathrm{Cr}_{2} \mathrm{O}_{7}\right)$ oxidation method according to Balasubramanian et al. (2011) and the volumetric ethanol productivity $(Q \mathrm{p})$ was calculated according to Onsoy et al. (2007).

\section{Characterization and identification of the selected} yeast isolate $Y 17$

\section{Phenotypic characterization}

The morphological characteristics such as colony shape, color, and texture as well as the microscopic features such as the cells shape, budding form of the selected isolate Y17 were conducted on YPDA, acetate agar and 5\% malt extract broth while the formation of pseudohyphae was studied on corn meal agar medium using the cover slip method (Lodder \& kreger-van, 1952).

\section{Genotypic identification}

DNA extraction and amplification: DNA extraction was conducted according to Kumar et al. (2010). The 18S rRNA encoding gene was amplified by the polymerase chain reaction (PCR) from purified genomic DNA using the two primers, 18SF: 5'-TTAAGCCATGCATGTCTAAG-3' (forward) and 18SR: 5'-GACTACGACGGTATCTAATC-3' (reverse) according to the methods of Hall et al. (1999). The PCR amplification was performed by using Qiagen Proof-Start Tag Polymerase Kit (Qiagen, Hilden, Germany). The following substrates were combined in $25 \mu \mathrm{l}$ including about 
50ng of template DNA, $12.5 \mu 1$ PCR Master Mix, $5 \mathrm{pmol}(0.5 \mu \mathrm{l})$ each of forward and reverse primers and the total reaction volume was completed by $11.5 \mu \mathrm{l}$ of water DNAase free water. The reaction mixture was incubated at an automated thermal cycle (Master cycler, Eppindorff, Germany) under the following conditions: temperature cycling comprised 35 cycles of DNA denaturation at $94^{\circ} \mathrm{C}$ for $30 \mathrm{sec}$, followed by annealing at $52^{\circ} \mathrm{C}$ for $30 \mathrm{sec}$ and extension at $72^{\circ} \mathrm{C}$ for $3 \mathrm{~min}$. Negative control was very important by addition of all above solutions without template DNA. Reactions were stopped by chilling at $4^{\circ} \mathrm{C}$. PCR products were analyzed by electrophoresis on $1 \%$ agarose TBE-gels (Tris-base Boric EDTA-gel) and the gels were visualized and pictured under UV light. PCR products were purified from gel with the QIA quick gel extraction kit (Qiagen, Hilden, Germany).

DNA sequencing: The amplified PCR products were sequenced (Macrogen Inc.) in both directions using an automatic DNA sequencer (3500 Genetic Analyzer, Applied Biosystems). The obtained sequence was aligned with most closely related taxa retrieved from GenBank using CLUSTALAW program (Thompson et al., 1997). Evolutionary tree was inferred using the neighbour-joining method using Treeviewx Program (Saitou \& Nei, 1987).

\section{Optimized conditions for bioethanol production}

Different environmental and nutritional parameters were conducted to maximize bioethanol value produced by the tested isolate from sugarcane molasses. The effects of different initial $\mathrm{pH}$ values $(3.0,3.5,4.0,4.5,5.0,5.5,6.0$ and 6.5) were assayed. Different molasses sugar concentrations $(5 \%-35 \%)$ with $5 \%$ intervals at the primary screening and then with $1 \%$ intervals at the secondary screening of the same experiment were tested. The cultures were fermented at different incubation temperatures $\left(25-45^{\circ} \mathrm{C}\right)$ with $5^{\circ} \mathrm{C}$ interval. The effect of different fermentation periods $(24,48,72,96,120$ and $144 \mathrm{~h})$ on ethanol production was estimated. The effect of different nitrogen sources (peptone, yeast extract, ammonium phosphate, ammonium sulfate and urea) on ethanol production was investigated.

\section{Statistical analysis}

Analysis of variance (ANOVA) was performed using CoStat V. 6.311 (CoHort software, Berkeley, CA94701). Ethanol production mean values were compared at 5\% significance level using Tukey's test. Least significant difference (LSD) test was used to test the significant differences between the whole means of different groups and compared with the critical difference at the 5\% level.

\section{$\underline{\text { Results }}$}

Fifteen yeast isolates were screened for their potentiality to produce bioethanol from sugarcane and beet molasses. The results presented in Table 2 showed all the tested yeast isolates were low ethanol producer from beet molasses with production and yield reaching $2.72 \%$ and $0.55 \mathrm{gL}^{-1} \mathrm{~h}^{-1}$, respectively. On the other hand, these isolates were significantly able to produce considerable amount of ethanol from sugarcane molasses. Out of the 15 tested yeast isolates, 7 isolates were able to produce more than or equal $7 \%$ ethanol during the fermentation of sugarcane molasses with productivity ranged between 1.45 and $1.78 \mathrm{gL}^{-1} \mathrm{~h}^{-1}$. It was worth mentioned that the highest ethanol producer isolate on sugarcane molasses was Y17 amounting 8.55\% and thus it was selected for further experiments.

TABLE 1. Composition of sugarcane and beet molasses used in this study.

\begin{tabular}{|c|c|c|c|c|c|c|}
\hline $\begin{array}{l}\text { Molasses } \\
\text { type }\end{array}$ & $\begin{array}{c}\text { Water } \\
\text { content } \\
\%\end{array}$ & $\begin{array}{c}\text { Ashes } \\
\%\end{array}$ & $\begin{array}{l}\text { Total } \\
\text { sugar } \\
\%\end{array}$ & $\begin{array}{c}\text { Total } \\
\text { nitrogen } \\
\%\end{array}$ & $\begin{array}{c}\text { Mineral } \\
\text { substances } \\
\%\end{array}$ & pH \\
\hline Sugarcane molasses & 20 & 11 & 52 & 3.4 & 6.2 & 5.2 \\
\hline Sugar beet molasses & 16 & 13 & 49.8 & 2.0 & 6.5 & 8.9 \\
\hline
\end{tabular}


TABLE 2. Ethanol production by the tested 15 yeast isolates at $18 \%$ of sugar sugarcane and beet molasses for $48 \mathrm{~h}$.

\begin{tabular}{|c|c|c|c|c|}
\hline \multirow{3}{*}{ Isolates code } & \multicolumn{4}{|c|}{ Ethanol production } \\
\hline & \multicolumn{2}{|c|}{ Sugarcane molasses } & \multicolumn{2}{|c|}{ Beet molasses } \\
\hline & EC\% $(v / v)$ & $\begin{array}{l}\text { Productivity } \\
\left(\mathrm{gL}^{-1} \mathbf{h}^{-1)}\right.\end{array}$ & EC\% $(v / v)$ & $\begin{array}{l}\text { Productivity } \\
\quad\left(\mathbf{g L}^{-1} \mathbf{h}^{-1}\right)\end{array}$ \\
\hline Y1 & $7.12 \pm 0.01^{\mathrm{c}}$ & 1.50 & $0.80 \pm 0.10^{\mathrm{g}}$ & 0.17 \\
\hline Y7 & $7.00 \pm 0.10^{\mathrm{c}}$ & 1.45 & $2.72 \pm 0.10^{\mathrm{a}}$ & 0.57 \\
\hline Y8 & $4.80 \pm 0.02^{\mathrm{d}}$ & 1.00 & $1.94 \pm 0.04^{\mathrm{c}}$ & 0.40 \\
\hline Y9 & $8.06 \pm 0.03^{b}$ & 1.68 & $1.72 \pm 0.20^{\text {cd }}$ & 0.36 \\
\hline Y11 & $4.22 \pm 0.02 \mathrm{~d}^{\mathrm{de}}$ & 0.88 & $2.45 \pm 0.05^{\mathbf{b}}$ & 0.51 \\
\hline Y13 & $2.98 \pm 0.14^{\mathrm{g}}$ & 0.62 & $2.66 \pm 0.02^{\mathrm{a}}$ & 0.55 \\
\hline Y17 & $8.55 \pm 0.01^{\mathrm{a}}$ & 1.78 & $1.69 \pm 0.01^{\mathrm{ce}}$ & 0.35 \\
\hline Y19 & $3.90 \pm 0.10^{\mathrm{f}}$ & 0.81 & $1.80 \pm 0.10^{\mathrm{cd}}$ & 0.37 \\
\hline Y30 & $4.00 \pm 0.08^{\mathrm{de}}$ & 0.83 & $2.33 \pm 0.30^{\mathbf{b}}$ & 0.49 \\
\hline Y31 & $3.72 \pm 0.10^{\mathrm{f}}$ & 0.78 & $1.40 \pm 0.20^{\mathrm{f}}$ & 0.29 \\
\hline Y33 & $4.11 \pm 0.45^{\mathrm{de}}$ & 0.86 & $0.80 \pm 0.1^{\mathrm{g}}$ & 0.17 \\
\hline Y36 & $4.77 \pm 0.07^{\mathrm{d}}$ & 0.99 & $1.73 \pm 0.01^{\mathrm{cd}}$ & 0.36 \\
\hline Y38 & $7.06 \pm 0.03^{\mathrm{c}}$ & 1.47 & $2.33 \pm 0.10^{\mathbf{b}}$ & 0.49 \\
\hline Y40 & $6.80 \pm 0.20^{\mathrm{c}}$ & 1.42 & $1.56 \pm 0.06^{\mathrm{ce}}$ & 0.32 \\
\hline Y45 & $6.67 \pm 0.20^{\mathrm{c}}$ & 1.38 & $1.60 \pm 0.20^{\mathrm{ce}}$ & 0.33 \\
\hline
\end{tabular}

Values are means of three replicates \pm standard deviation and the values with the same letters are not significantly different.

\section{Identification of the yeast isolate Y17}

The identification of yeast isolate Y17 was based on phentotypic characterization and genotypic analysis. Phenotypic characterization included the morphological growth characters and biochemical characters revealed that the isolate Y17 is Saccharomyces cerevisiae as shown in Table 3. The shape of cells and budding of the isolate on YPDA, acetate agar, malt extract broth and corn meal agar media are shown in Fig. 1. Subsequently, the alignment analysis of 18S rRNA gene sequence of the isolate Y17 with related sequences obtained from GenBank database revealed that the yeast isolate Y17 is closely similar to Saccharomyces cerevisiae strain DAOM 216365 (JN938990) with 99\% nucleotides identity (Fig. 2). The selected isolate Y17 sequence was deposited in the GenBank under the accession number KP096551.

\section{Optimization conditions for alcoholic fermentation} process

Parameters such as $\mathrm{pH}$, temperature, substrate concentration and nitrogen source were investigated to obtain maximum yield of bioethanol by Saccharomyces cerevisiae Y17 from sugarcane molasses.
Effect of pretreatment process on bioethanol production

The pretreatment of sugarcane molasses using sulfuric acid gave an effective impact on the fermentation process by S. cerevisiae Y17. Whereas, high ethanol production $(8.55 \%)$ was obtained after the pretreatment of molasses by sulfuric acid. On the other hand, the using of nitric and phosphoric acids, in the pretreatment process caused in ethanol production by 8.06 and $7.51 \%$, respectively (Fig. 3).

Effect of different hydrogen ion concentrations

Bioethanol concentration gradually increased along with the increase in $\mathrm{pH}$ and reached the maximum percentage of bioethanol production at pH 4.5 to be 8.55 (v/v) (Fig. 4). The optimum $\mathrm{pH}$ value 4.5 was selected for completing the further experiments.

Effect of different molasses sugar concentrations

Figure 5a showed that the concentration of bioethanol enhanced along the increase in sugar concentration. The maximum ethanol production at sugar concentration was obtained at $15-20 \%$ of molasses. Furthermore, screening on molasses 
sugar concentration was conducted using $1 \%$ intervals between $15-20 \%$ to determine the exact sugar concentration. Figure $5 b$ showed that the highest concentration of bioethanol was determined at $18 \%$ sugar. Further increasing in sugar molasses concentration resulted in decrease the bioethanol production.

TABLE 3. Morphological and biochemical characteristics of the isolate Y17.

\section{Obvious}

\begin{tabular}{|c|c|c|c|}
\hline \multirow{4}{*}{ 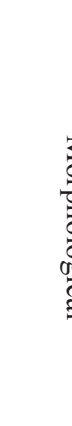 } & & $\begin{array}{l}\text { Yeast extract peptone } \\
\text { dextrose agar }\end{array}$ & $\begin{array}{l}\text { Colonies is butyrous and light cream-colored with smooth surface, raised } \\
\text { and opaque. }\end{array}$ \\
\hline & 3 & $5 \%$ Malt broth & $\begin{array}{l}\text { Cells are subglobose to ovoidal, budding is monobloar, bipolar and } \\
\text { multilateral. }\end{array}$ \\
\hline & 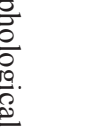 & Acetate agar & $\begin{array}{l}\text { Cultures are smooth and white to cream in color. Cells are large and } \\
\text { subglobose to ovoidal with large nuclei. Vegetative cells are transformed } \\
\text { into asci with four ascospores }\end{array}$ \\
\hline & & Corn meal agar & Pseudohyphae are rudimentary bearing chains of ovoidal blastoconidia. \\
\hline \multirow{23}{*}{ 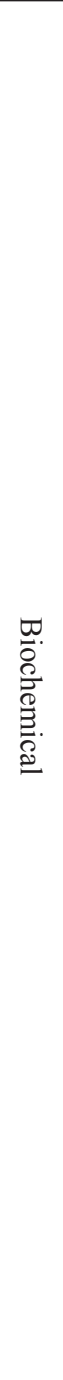 } & & Glucose & $+\mathrm{ve}$ \\
\hline & & Sucrose & $+\mathrm{ve}$ \\
\hline & $\stackrel{T}{9}$ & Lactose & -ve \\
\hline & $\stackrel{\Xi}{\Xi}$ & Raffinose & $+\mathrm{ve}$ \\
\hline & & Trehalose & -ve \\
\hline & \multirow{13}{*}{ 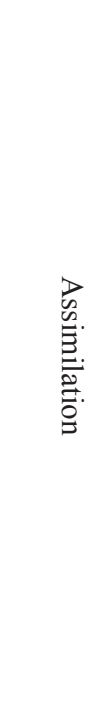 } & Glucose & $+\mathrm{ve}$ \\
\hline & & Galactose & $+\mathrm{ve}$ \\
\hline & & Sucrose & $+\mathrm{ve}$ \\
\hline & & Raffinose & $+\mathrm{ve}$ \\
\hline & & Maltose & $+\mathrm{ve}$ \\
\hline & & Lactose & -ve \\
\hline & & Cellobiose & -ve \\
\hline & & Trehalose & $+\mathrm{ve}$ \\
\hline & & Soluble starch & -ve \\
\hline & & L-Arabinose & -ve \\
\hline & & L-Rhamnose & -ve \\
\hline & & D-Mannitol & -ve \\
\hline & & citrate & -ve \\
\hline & \multicolumn{2}{|c|}{ Catalase production } & $+\mathrm{ve}$ \\
\hline & \multicolumn{2}{|c|}{ Urease production } & -ve \\
\hline & \multicolumn{2}{|c|}{ Nitrate reduction } & -ve \\
\hline & \multicolumn{2}{|c|}{ Growth at $37^{\circ} \mathrm{C}$} & $+\mathrm{ve}$ \\
\hline & \multicolumn{2}{|c|}{ Growth at $2 \% \mathrm{NaCl}$} & $+\mathrm{ve}$ \\
\hline
\end{tabular}



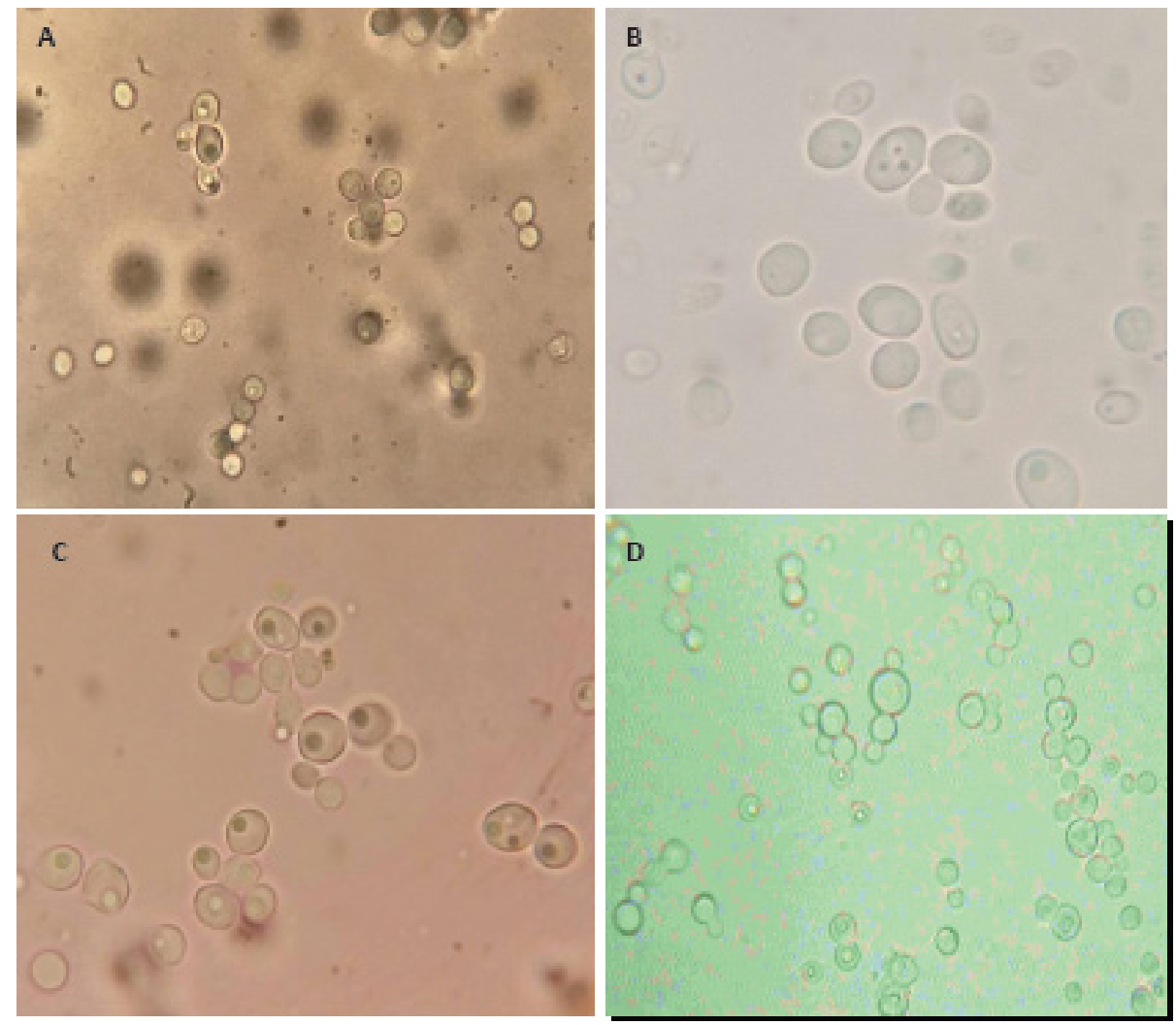

Fig. 1. Saccharomyces cerevisiae Y17 (KP096551) on (A) YPDA, (B) Acetate agar, (C) Malt extract broth and (D) Corn meal agar.

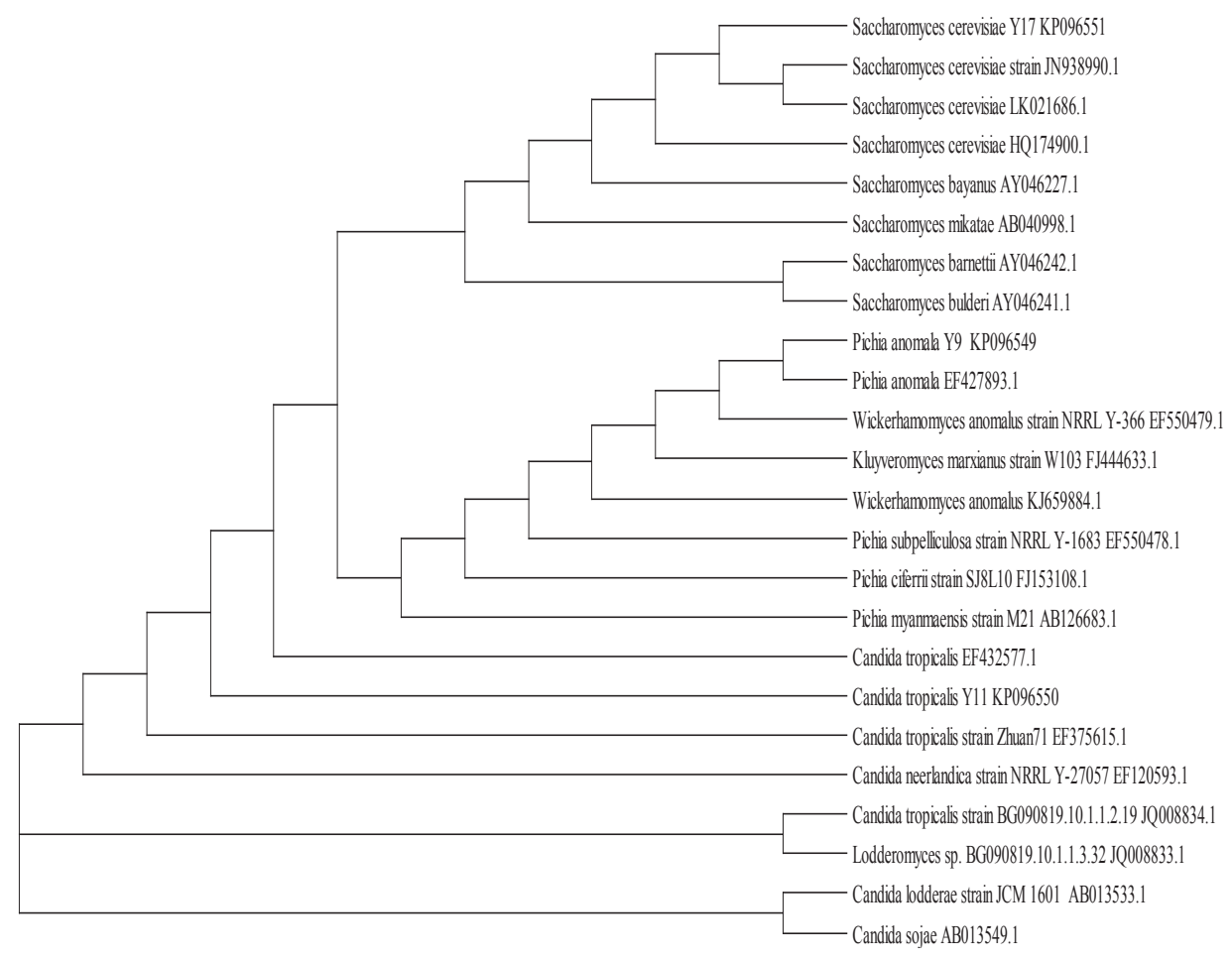

Fig. 2. Phylogenetic tree of nucleotide sequence of Saccharomyces cerevisiae Y17 matching with different neighbor sequences.

Egypt. J. Bot. 58, No. 3 (2018) 


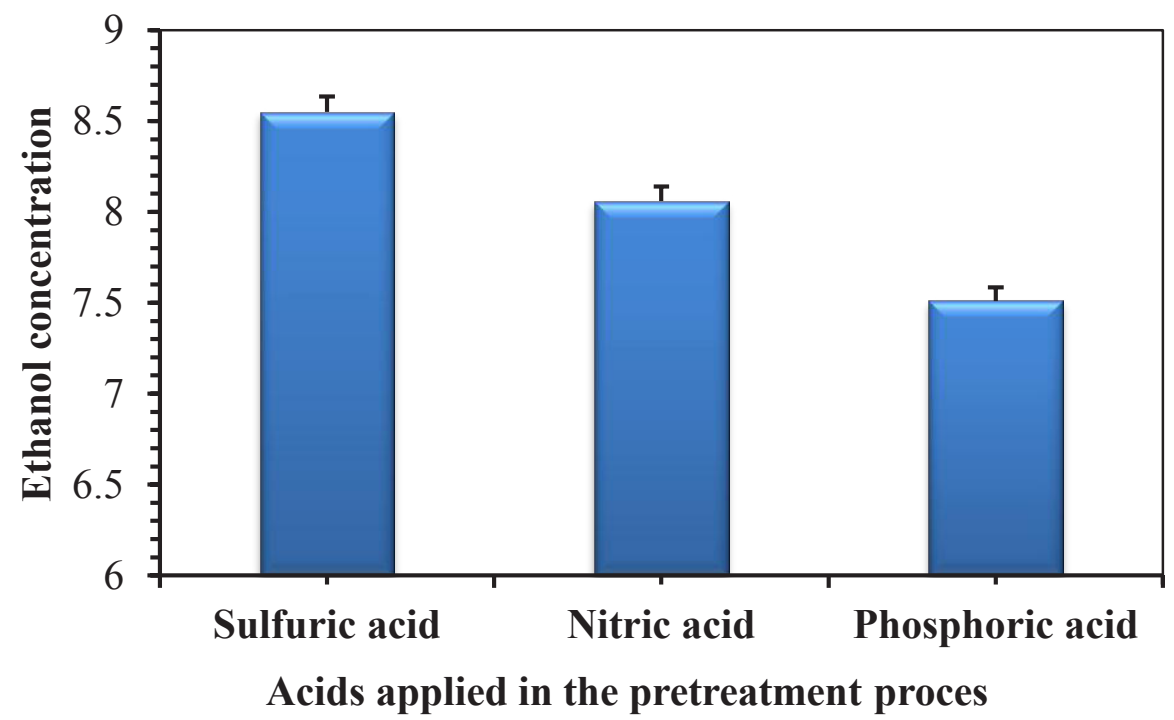

Fig. 3. Ethanol production from $15 \%$ molasses by $S$. cerevisiae Y17 during the application of different acids in the pretreatment process.

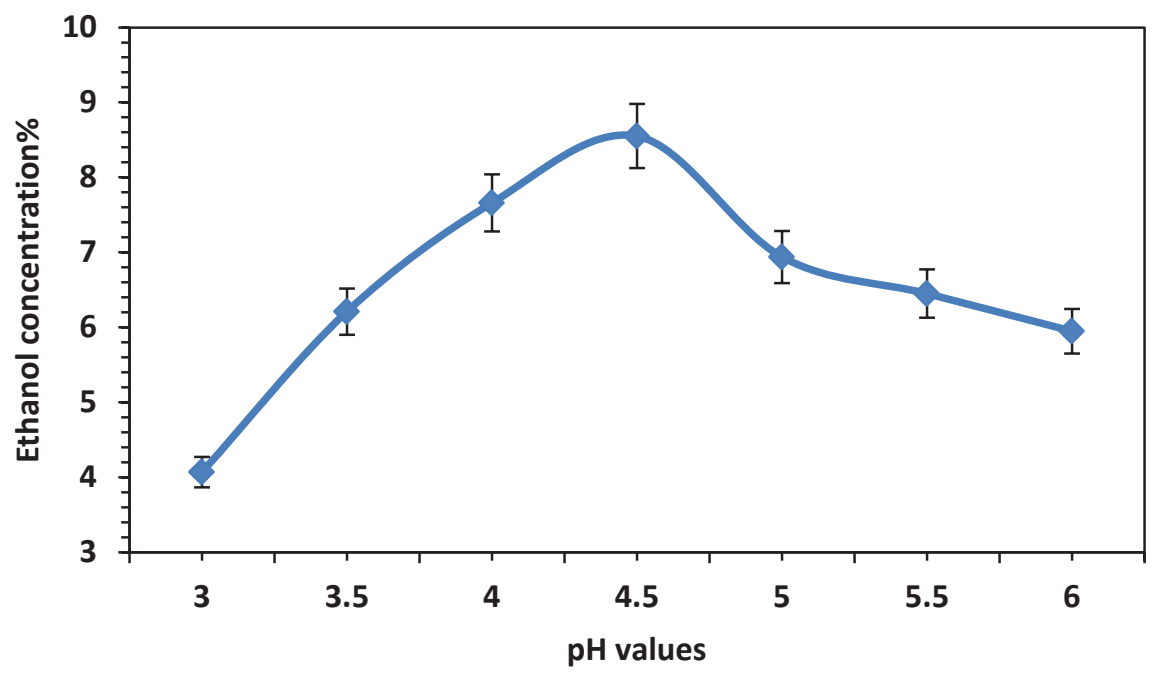

Fig. 4. Ethanol production level by $S$. cerevisiae $\mathrm{Y} 17$ as affected with different initial $\mathrm{pH}$ values.

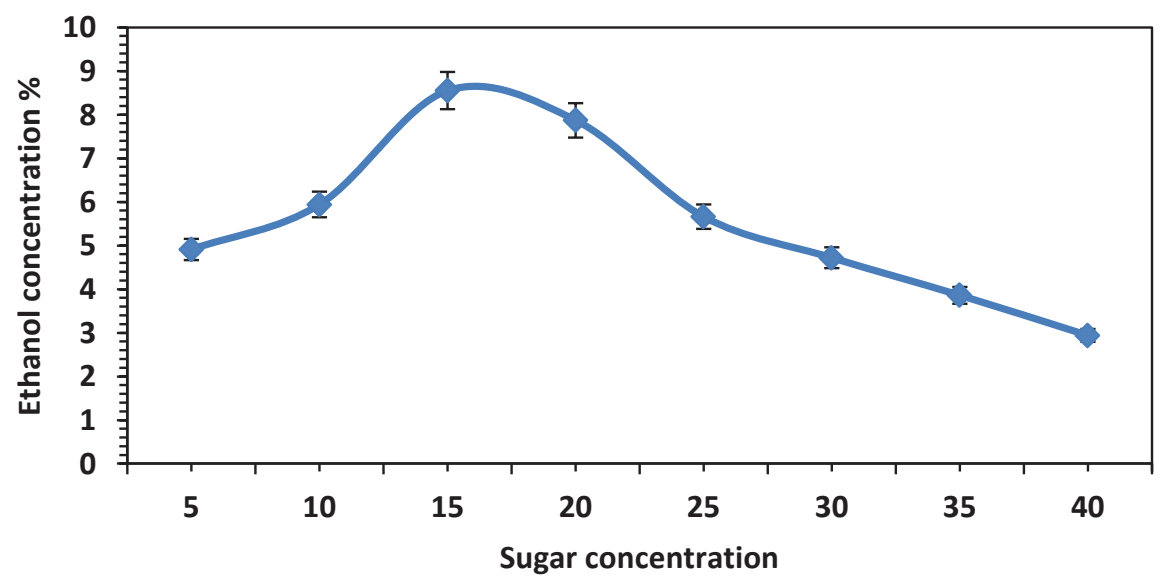

Fig. 5a. Ethanol production level by $S$. cerevisiae $\mathrm{Y} 17$ as affected with different initial molasses sugar concentration with $\mathbf{5 \%}$ intervals. 


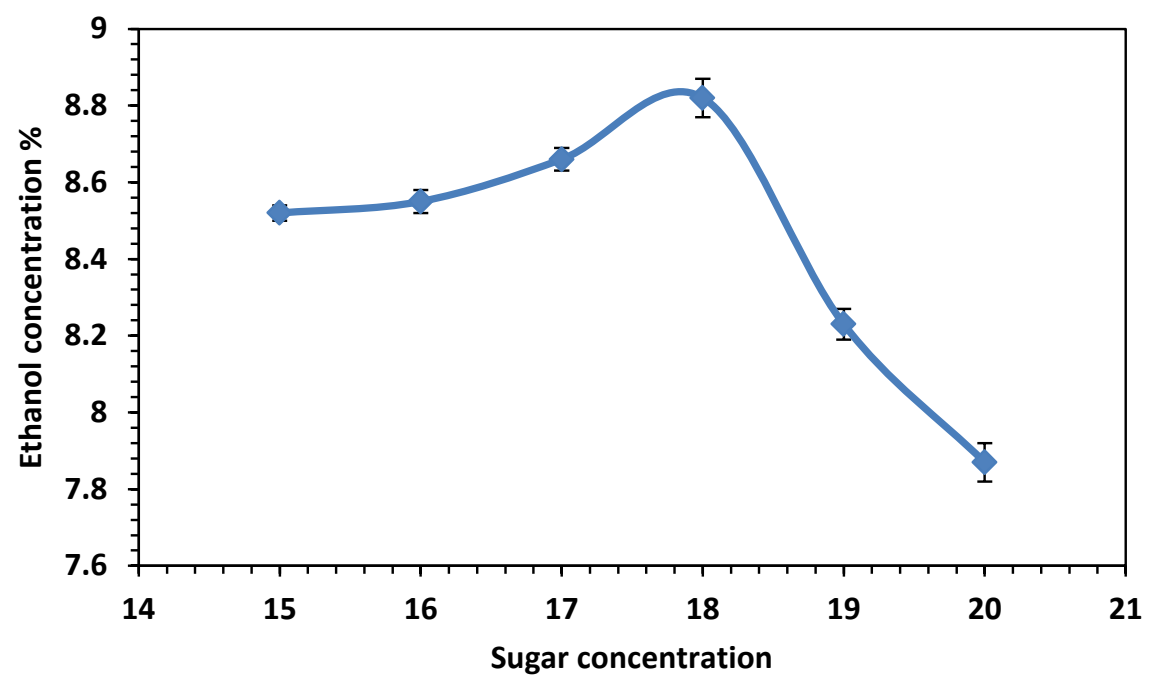

Fig. 5b. Ethanol production level by $S$. cerevisiae Y17 as affected with different initial molasses sugar concentration with $1 \%$ intervals.

Effect temperatures and fermentation period on bioethanol production

Bioethanol production by Saccharomyces cerevisiae Y17 increased with the increase in temperature and reached the maximum value at $30^{\circ} \mathrm{C}$ (Fig. 6). Further increase in temperature reduced the percentage of ethanol production.

The results showed that the bioethanol production increased as the fermentation period progressed (Fig. 7). After 24h, the bioethanol concentration was $6.67 \%$ with productivity of $2.78 \mathrm{gL}^{-1} \mathrm{~h}^{-1}$. The bioethanol production increased after $48 \mathrm{~h}$ to $8.82 \%(\mathrm{v} / \mathrm{v})$ with productivity of $1.83 \mathrm{gL}^{-1} \mathrm{~h}^{-1}$. After $72 \mathrm{~h}$, the bioethanol production percentage gradually increased to be 9.18 but with clear decrease in the productivity to $1.28 \mathrm{gL}^{-1} \mathrm{~h}^{-1}$. The optimum ethanol production $(9.55 \%)$ was achieved after $96 \mathrm{~h}$ with a further decrease in the productivity $\left(0.99 \mathrm{gL}^{-1} \mathrm{~h}^{-1}\right)$. also, the further increase in the fermentation period showed a gradual decrease in both of the bioethanol concentration and the productivity.

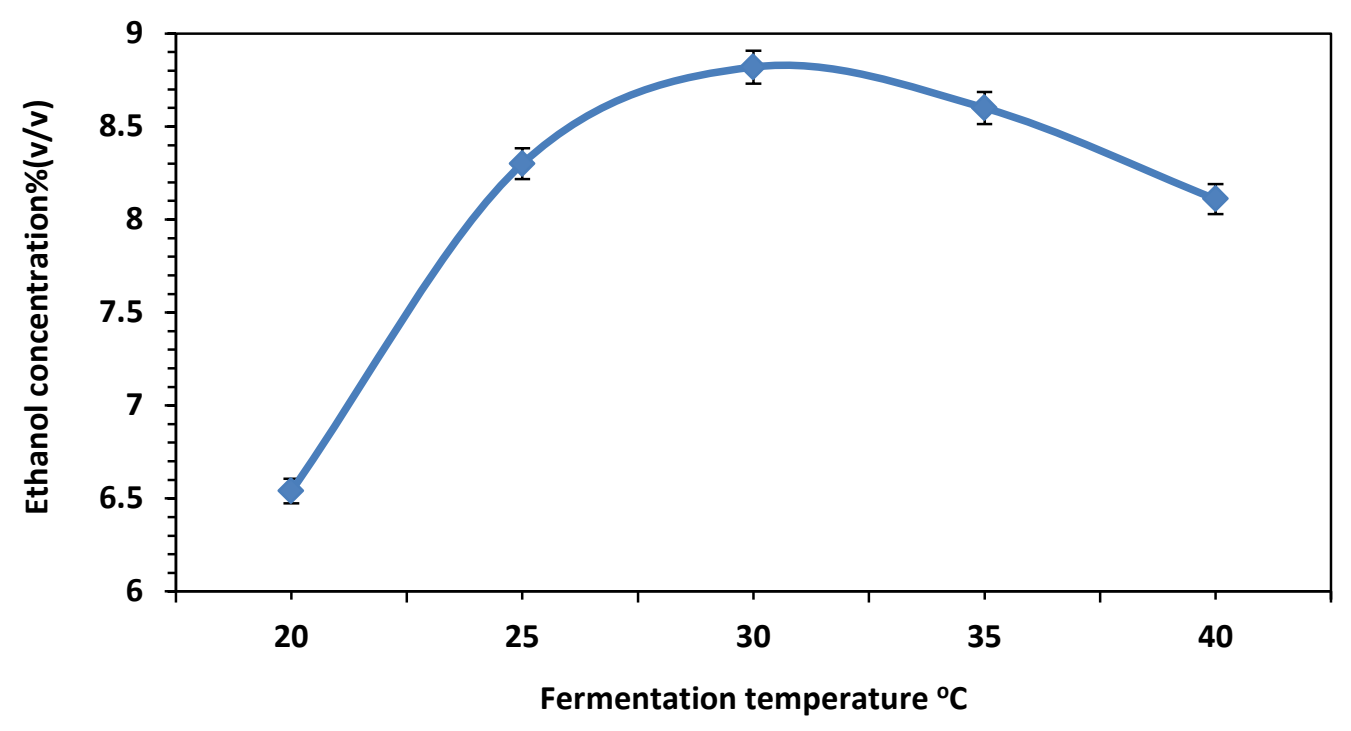

Fig. 6. Ethanol production level \% (v/v) by S. cerevisiae $\mathrm{Y} 17$ at different fermentation temperatures. 


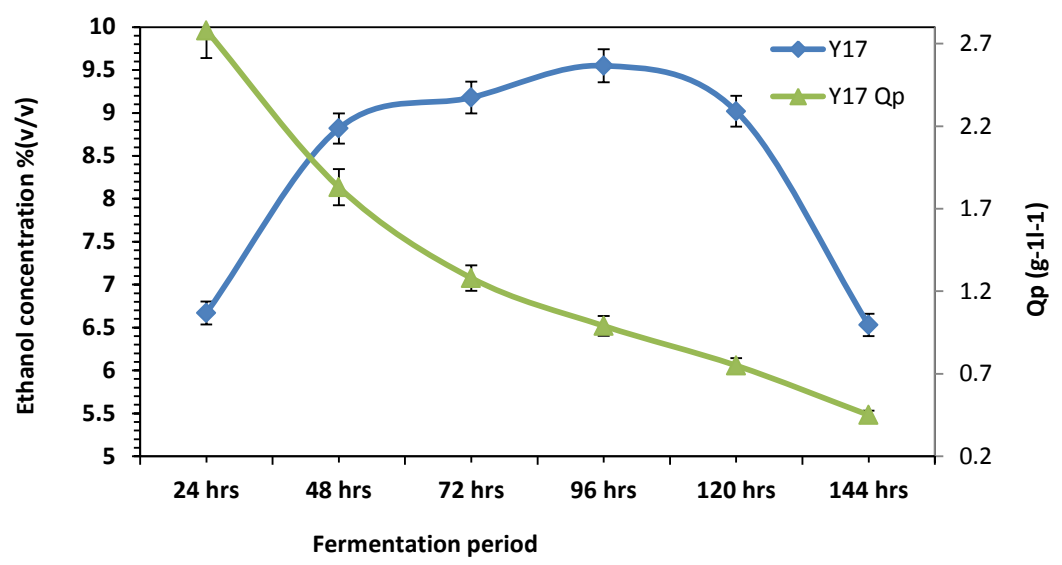

Fig. 7. Ethanol production level and volumetric ethanol productivity by $S$. cerevisiae Y17 at different fermentation periods.

\section{Effect of different nitrogen sources on bioethanol production}

This study demonstrated that the supplementation of different organic and inorganic nitrogen sources (peptone, yeast extract, ammonium phosphate, ammonium sulfate and urea) significantly stimulated the ethanol production by S. cerevisiae Y17 (Table 4). The maximum ethanol production was associated with addition of yeast extract as nitrogen source in the fermentation medium reaching 9.84\%. Urea represented the second nitrogen source that enhanced the ethanol production to $9.82 \%$. Also, peptone improved the ethanol production to $9.72 \%$. On the other hand, the inorganic nitrogen sources ammonium sulfate and ammonium phosphate caused considerable increase in ethanol production to 9.76 and $9.67 \%$, respectively. The ethanol production in the control was $9.55 \%$ (Table 4).

TABLE 4. Ethanol production by $\boldsymbol{S}$. cerevisiae Y17 as affected with different nitrogen sources at optimum fermentation conditions.

\begin{tabular}{lcc}
\hline \multirow{2}{*}{$\begin{array}{l}\text { Nitrogen } \\
\text { source }\end{array}$} & \multicolumn{2}{c}{ Ethanol production } \\
\cline { 2 - 3 } EC\% & $\begin{array}{c}\text { Productivity } \\
\left(\mathbf{g L}^{-1} \mathbf{h}^{-1}\right)\end{array}$ \\
\hline Control & $9.55^{\mathrm{a}} \pm .05$ & 1.99 \\
$\begin{array}{l}\text { Amm. } \\
\text { phosphate }\end{array}$ & $9.67^{\mathrm{b}} \pm .02$ & 2.01 \\
$\begin{array}{l}\text { Amm. } \\
\text { sulphate }\end{array}$ & $9.76^{\mathrm{c}} \pm .03$ & 2.03 \\
$\begin{array}{l}\text { Peptone } \\
\text { Urea }\end{array}$ & $9.72 \mathrm{~b}^{\mathrm{c}} \pm .02$ & 2.02 \\
$\begin{array}{l}\text { Yeast } \\
\text { extract }\end{array}$ & $9.82^{\mathrm{d}} \pm .07$ & 2.04 \\
\hline
\end{tabular}

\section{Discussion}

The industrial revolution has been accompanied by an increase in energy needs. Today, fossil fuel is the backbone of the industrial revolution and world energy demand. Alternative energy-related research currently receives immense attention, mostly in relation to the cost of petroleum oil, global warming issue and increased depletion of fossil fuel reserves (Foley \& Olabi, 2017). Consequently, interest in liquid biofuels fermentation, which declined following the development of the petrochemical industry, has been retrieved (AbdAlla et al., 2015). However, a major challenge hampering recommercialization of the $\mathrm{ABE}$ process is lack of economic competitiveness due to the absence of inexpensive, sustainable and easily fermentable substrates capable of generating high ABE yields. In Egypt, these are no clear economic and environmental strategies for the utilization of molasses. Therefore, this study aims to explore the possibility of using these wastes as a renewable and inexpensive substrate for ethanol production.

The current study demonstrated that the fifteen tested yeast isolates were able to utilize sugarcane molasses producing considerable amount of ethanol. However, these isolates were lower ethanol producers from beet molasses. The inhibition of some yeast isolates during bioethanol fermentation of molasses might be due to the presence of different toxic substances that can affect yeast growth. Variable amounts of herbicides, insecticides, fungicides, fertilizers and heavy metals applied to beet or cane crops can be found in molasses and in different stocks. Moreover bactericides, which are added during sugar production in refinery plants, can be found (Reed \& Nagodawithana, 
1988). All these toxic substances can decrease yeast performance by inhibiting their growth (Pérez-Torrado et al., 2009). Patrascu et al. (2009) reported that the ethanol yield from molasses was differed depending on the yeast strain used for fermentation. In this study, seven isolates out of the 15 tested yeast isolates were able to produce more than $6 \%(\mathrm{v} / \mathrm{v})$ ethanol concentration in the fermented media. Other seven yeast isolates were moderate ethanol producer and only one isolate was low ethanol producer with less than $3 \%(\mathrm{v} / \mathrm{v})$ concentration from sugarcane molasses. On the other hand, none of the 15 selected isolates had the capability to produce more than $3 \%(\mathrm{v} / \mathrm{v})$ ethanol concentration from beet molasses. However, Zohri et al. (2012) used Egyptian beet molasses and recorded that the highest level of ethanol production was $9.2(\mathrm{v} / \mathrm{v})$ at $20 \%$ molasses sugar for $72 \mathrm{~h}$. This difference in the results might be due to the difference in beet molasses composition, hydrogen concentration, the inhibitors that might present in the molasses and the strains that used.

The conventional phenotypic methods as well as the traditional physiological and biochemical identification tests are not reliable, time consuming and not so precise (Garner et al., 2010). Molecular approaches for characterization and identification, have in part, replaced the traditional methods and are based on DNA base composition, genome association, gene sequencing and PCR based methods (Baleiros-Couto et al., 1994 and Nisiotou \& Gibson, 2005). Therefore, the genotypic identification based on phylogenetic analysis was used to identify the selected isolate in this study. Our results showed that the tested isolate Y17 was belonging to family Saccharomycetaceae and identified as Saccharomyces cerevisiae. S. cerevisiae strains have been identified as the yeast of choice for efficient bioethanol fermentation due to their ability to convert hexose sugars to high concentrations of ethanol despite the presence of inhibitory compounds in medium (Lin \& Tanka, 2006).

During industrial scale production of ethanol from molasses fermentation, there were various factors that affect yeast growth as well as fermentative metabolism. The culture conditions such as $\mathrm{pH}$, temperature, sugar concentration, etc. together with effect of additives had profound effect on ethanol production (Jones et al., 1981). So, these factors were investigated to obtain the maximum yield of bioethanol using sugarcane molasses. The $S$. cerevisiae Y17 was selected for the optimization due to its high ability to produce ethanol $(8.55 \%(\mathrm{v} / \mathrm{v}))$ from sugar cane molasses. The selected isolate produced the highest ethanol concentration when the medium $\mathrm{pH}$ was adjusted using sulfuric acid. This is supported by Lazaridou et al. (2002) who found that sulfuric acid reduced the harmful compounds found in molasses. The results in this study showed that the bioethanol concentration gradually increased along with the increase in molasses $\mathrm{pH}$ and reached a maximum percentage of bioethanol production at $\mathrm{pH} 4.5$ and then it started to decline. An optimum $\mathrm{pH}$ of 4.5 was also reported by many investigators (Nadeem, 1992; Yadav et al., 1997; Bhandari, 1999 and Reed, 2001).

Increasing sugar concentration gave a high yield of ethanol during fermentation. However, Jones et al. (1994) found that the very high sugar concentrations are inhibitory to fermentation due to increasing osmotic stress. Borzani et al. (1993) demonstrated the logarithmic relationship between time of fermentation and initial concentrations of sugar. Javid (1994) reported that at the fermentation with $17 \%$ sugar concentration, a saturation limit was reached and the sugar repression of the enzymes in fermentative pathway became more significant causing the slower conversion rate. This could be the explanation of the results obtained in this study that the bioethanol yield increased along with the increase in sugar concentration and reach maximum ethanol production at sugar concentration of $18 \%$ and then decreased with increasing sugar concentration. Zohri \& Mostafa (2000) found that increasing sugar concentration lead to increase the viscosity in fermentation medium which had an inhibitory effect on yeast growth and their ethanol production capability. Also, Reddy \& Reddy (2006) reported that increasing in sugar concentration will lead to a decrease in sugar utilization, which results in reduction of the total ethanol production.

The fermentation process accompany with evolution of heat that raises the fermentor temperature and it becomes necessary to cool the large fermentors in the industry, this major operation is of a high necessity and a cost factor in the production of ethanol (Zohri et al., 2012). It is well known that temperature affect growth, metabolism and bioethanol production capability of the fermenting organism. During 
this investigation, bioethanol production by the selected isolate increased with the increase in temperature and reaches maximum value at $30^{\circ} \mathrm{C}$. These results were consistent with Sedha et al. (2000) and Ali (2010). Further increase in temperature reduced the ethanol production and this might be due to changing the transport activity or saturation level of soluble compounds and solvents in the cells, which might increase the accumulation of toxins including ethanol inside cells (Phisalaphong et al., 2006). The indirect effect of high temperature might also be ascribed to the denaturation of ribosomes and enzymes and the problems with the fluidity of membranes (Gao \& Fleet, 1988).

During ethanol production on the industrial scale, yeast may be confronted with a variety of environmental stresses that can cause the loss of yeast cell viability, reduction of yeast growth and increasing fermentation times which in turn decreased fermentation rates (Graves et al., 2007). Fermentation period is a very important factor from an economic point of view in ethanol production. Our results revealed that the ethanol yield was reaching its maximum after $96 \mathrm{~h}(9.55 \%(\mathrm{v} / \mathrm{v})$ for S. cerevisiae Y17. However, the volumetric productivity of the selected yeast isolate was dramatically decreased during this fermentation time, so from an economic point of view, it could be estimated that the optimum ethanol production had been achieved after $48 \mathrm{~h}$ as both ethanol production and the volumetric productivity were at very high levels. On the other hand, Suryawati et al. (2008) and Faga et al. (2010) reported that the appropriate time for different strains of Kluyveromyces marxianus to produce the highest amount of ethanol was $72 \mathrm{~h}$. So it is clear that the appropriate fermentation time for the optimum ethanol production depend on the organism as well as the conditions of production.

Nitrogen deficiency slows down yeast growth and the fermentation possibly due to the inhibition of the protein synthesis that transports sugars to the interior of the cells through cell membrane (Butzke \& Dukes, 1996). It has been shown that adequate nitrogen increases yeast growth provided that the other essential yeast nutrient is not lacking (Nofemele et al., 2012). Different organic nitrogen sources (peptone, urea, yeast extract) and inorganic nitrogen sources (ammonium phosphate and ammonium sulphate) were investigated as possible nitrogen supplements for the molasses.
These results showed that all nitrogen sources investigated had a positive effect on the ethanol yield. The maximum ethanol production was obtained with the organic nitrogen source "yeast extract" where the recorded ethanol concentration was $9.84 \% \quad(\mathrm{v} / \mathrm{v})$. Yeast extract provides convenient growth factors for microbial growth (Nancib et al., 2001 and Ortiz-Muniz et al., 2010). These results were in agreement with Zayed \& Foley (1987) and El-Refai et al. (1992) who found that the addition of urea significantly improved the ethanol yield. Junior et al. (2008) found that peptone improved the fermentation performance of the yeast which was in agreement with the results obtained in this study. On the other hand, it was observed that ammonium sulphate was a good inorganic nitrogen source that stimulated the ethanol production. Ammonium sulphate had been chosen as inorganic nitrogen source for future experiments as it is a simple source that can enter the cell directly (Mendes-Ferreira et al., 2004). Ammonium sulphate is a common and efficient nitrogen source for microbial growth; it is cheap and does not produce a toxic effect towards the microbial enzymes (Bamforth, 2005).

\section{Conclusion}

The Saccharomyces cerevisiae Y17 KP096551 could be very effective and is potential microbial inoculant for production of bioethanol from sugarcane molasses on large scale.

\section{References}

Abd-Alla, M.H., Zohri, A.N.A., El-Enany, A.W.E. and Ali, S.M. (2015) Acetone-butanol-ethanol production from substandard and surplus dates by Egyptian native Clostridium strains. Anaerobe, 32, 77-86.

Ali, M.M. (2010) Studies on production of ethanol and single cell proteins by local yeast strains. M.Sc. Thesis, Botany Department, Faculty of Science, Assiut University, Assiut, Egypt.

Balasubramanian, K., Ambikapathy, V. and Panneerselvam, A. (2011) Studies on ethanol production from spoiled fruits by batch fermentations. J. Microbiol. Biotechnol. Res. 1(4), 158-163.

Baleiros-Couto, M.M., Vogels, J.T., Hofstra, H., Huisin't Veld, J.H.J. and Van Der Vossen, J.M. 
(1994) RAPD analysis: A rapid technique for differentiation of spoilage yeasts. Int. J. Food Microbiol. 24, 249-260.

Bamforth, C.W. (2005) The science underpinning food fermentations, In: "Fermentation and Microorganisms", Blackwell Science Ltd Publishing (Ed.), 1, pp.78-84. Oxford, UK. .

Bazmi, A.A., Bhutto, A.W. and Ghauri, M. (2007) Ethanol fuel as feasible and desired option in Pakistan. ESDev, CIIT Abbott abad, Pakistan, 1, 247-258.

Bhandari, H.C. (1999) Studies on preclarification of molasses and its effect on alcoholic fermentation by S. cerevisiae. Indian Mirr Publishers 1, 83-84.

Bhatia, L., Johri, S. and Ahmad, R. (2012) An economic and ecological perspective of ethanol production from renewable agro waste: A review. AMB Express J. 2(1), 65 .

Borzani, W., Garab, A., Pires, M.H., Piplovic, R. and De IaHiguera, G.A. (1993) Batch ethanol fermentation of molasses: A correlation between the time necessary to complete the fermentation and the initial concentrations of sugar and yeast cells. World J. Microbiol. Biotechnol. 9, 265-68.

Butzke, C.E. and Dukes, B.C. (1996) Detection and consequences of nitrogen deficiencies in must. Wine Spoilage Microbiology Conference CATI Publication, 960203, California State University, Fresno, Calif, USA.

Chandra, J. and Panchal, F. (2003) "Yeast Strain Selection". Bioprocess Technol. Series. Marcel dekker Pub. New York, pp. 349.

Dodić, S., Popov, S., Dodić, J., Ranković, J., Zavargo, Z. and Mučibabić, J. (2009) Bioethanol production from thick juice as intermediate of sugar beet processing. Biomass Bioenerg, 33, 822-827.

El-Gendy, N.S., Madian, H.R. and Abu Amr, S.S. (2013) Design and optimization of a process for sugarcane molasses fermentation by Saccharomyces cerevisiae using response surface methodology. Int. J. Microbiol. 2013, 1-9.

El-Refai, A.H., El-Abyad, M.S., El-Diwany, A.I., Sallam, L.A. and Allam, R.F. (1992) Some physiological parameters for ethanol production from beet molasses by Saccharomyces cerevisiae Y-7. Bioresour. Technol. 42, 183-189.

El-Samman, A.A. (2010) Organic and inorganic constituents analysis of molasses and its effect on microbial fermentation industries. Ph.D. Thesis, Sugar Technology Research Institute, Assiut University, Assiut, Egypt.

El-Tantawy, K.S.A. (2012) Studies on alcoholic fermentation for beet molasses. M.Sc. Thesis, Sugar Technology Research Institute, Assiut University, Assiut, Egypt.

Faga, B.A., Wilkins, M.R. and Banat, I.M. (2010) Ethanol production through simultaneous saccharification and fermentation of switch grass using Saccharomyces cerevisiae D5A and thermotolerant Kluyveromyces marxianus IMB strains. Bioresour. Technol. 101, 2273-2279.

Foley, A. and Olabi, A.G. (2017) Renewable energy technology developments, trends and policy implications that can underpin the drive for global climate change. Renew Sustainable Energy Rev. 68, Part 2, 1112-4.

Gao, C. and Fleet, G.H. (1988) The effects of temperature and $\mathrm{pH}$ on the ethanol tolerance of the wine yeasts: Saccharomyces cerevisiae, Candida stellate and Kloeckera apiculata. J. Appl. Bacteriol. 65(5), 405-409.

Garner, C.D., Starr, J.K. and McDonough, P.L. (2010) Molecular identification of veterinary yeast isolates by use of sequence-based analysis of the D1/ D2 region of the large ribosomal subunit. J. Clin. Microbiol. 48(6), 2140-2146.

Graves, T., Narendranath, N. and Power, R. (2007) Development of a stress model fermentation system for fuel ethanol yeast strains. J. Inst. Brew. 113(3), 263-271.

Gurav, M.S. and Geeta, G.S. (2007) Effectiveness of fungal pretreatment of agro residues on ethanol production by yeasts and Zymomonas mobilis. Karnataka J. Agric. Sci. 20(2), 301-304.

Hall, A., Bindslev, L., Rouster, J., Rasmussen, S., Oliver, R.P. and Gurr, S.J. (1999) Involvement of CAMP and protein kinase A in conidial differentiation by Erysiphe graminis. Mol. Plant Microbe. 12, 960968. 
Hawary, H.H. (2014) Fungal mediated ethanol production from agro-industrial wastes. M.Sc. Thesis, Botany Department, Faculty of Science, Suez Canal University, Ismailia, Egypt.

Izmirlioglu, G. and Demirci, A. (2012) Ethanol production from waste potato mash by using Saccharomyces cerevisiae. Appl. Sci. 2(4), 738-753.

Javid, M.A. (1994) The effect of concentration of molasses and quality of yeast on the recovery of alcohol from cane molasses. M.Sc. Thesis, Dept. of Technology University of Agricultural, Faisalabad.

Jones, A.M., Thoma,s K.C. and Inglew, W.M. (1994) Ethanolic fermentation of molasses and sugarcane juice using very high gravity technology. J. Agric. Food Chem. 42, 1242-1246.

Jones, R., Pamment, P.N. and Greenfied, P.F. (1981) Alcoholic fermentation by yeasts, the effect of environment and other variables. Process Biochem. 16, 42-49.

Junior, M., Batistote, M. and Ernandes, J. (2008) Glucose and fructose fermentation by wine yeasts in media containing structurally complex nitrogen sources. J. Inst. Brew. 114, 199-204.

Kumar, A., Poonam, B. and Lal, C.R. (2010) Isolation and molecular characterization of phosphate solubilizing Enterobacter and Exiguobacterium species from paddy fields of Eastern Uttar Pradesh, India. Afr. J. Microbiol. Res. 4, 820-829.

Lavarack, B.P. (2001) Technical mission to India: Alcohol production, biomethanisation, cogeneration. SRI Technical Report No. 05/01.

Lazaridou, A., Roukas, T., Biliaderis, C.G. and Vaikousi, H. (2002) Characterization of pullulan produced from beet molasses by Aureobasidium pullulans in a stirred tank reactor under varying agitation. Enz. Microbiol. Technol. 31, 122-132.

Lin, Y. and Tanka, S. (2006) Ethanol fermentation from biomass resources: Current state and prospects. Appl. Microbiol. Biotechnol. 69, 627-642.

Lodder, J. and Kreger-Van, Rij N.J.W. (1952) "The Yeasts: A Taxonomic Study", Amsterdam: NorthHolland Pub. New York: Interscience, pp. 713.

Mendes-Ferreira, A., Mendes-Faia, A. and Leão,
C. (2004) Growth and fermentation patterns of Saccharomyces cerevisiae under different ammonium concentrations and its implications in wine making industry. J. Appl. Microbiol. 97, 540545.

Nadeem, T.M. (1992) Development of the optimum conditions of microorganisms to utilize molasses for the production of vinegar. M.Sc. Thesis, Department of food technology. University of Agriculture, Faisalabad Pakistan.

Nancib, N., Nancib, A., Boudjelal, A., Benslimane, C., Blanchard, F. and Boudrant, J. (2001) The effect of supplementation by different nitrogen sources on the production of lactic acid from date juice by Lactobacillus casei subsp. Rhamnosus. Bioresour. Technol. 78, 149-153.

Nguyen, T.L.T., Hermansen, J.E. and Sagisaka, M. (2009) Fossil energy savings potential of sugar cane bioenergy systems. Appl. Energy, 86, 132-139.

Nisiotou, A.A. and Gibson, G.R. (2005) Isolation of culturable yeasts from market wines and evaluation of the 5.8S-ITS rDNA sequence analysis for identification purposes. Lett. Appl. Microbiol. 41, 454-463.

Nofemele, Z., Shukl, P., Trussler, A., Permaul, K. and Singh, S. (2012) Improvement of ethanol production from sugar cane molasses through enhanced nutrient supplementation using Saccharomyces cerevisiae. J. Brew. Distill. 3(2), 29-35.

Onsoy, T., Thanonkeo, P., Thanonkeo, S. and Yamada, M. (2007) Ethanol production from Jerusalem artichoke by Zymomonas mobilis in batch fermentation. KMITL Sci. Tech. J. 7, 55-60.

Ortiz-Muniz, B., Carvajal-Zarrabal, O., TorrestianaSanchez, B. and Aguilar -Uscanga, M.G. (2010) Kinetic study on ethanol production using Saccharomy cescerevisiae ITV-01 yeast isolated from sugarcane molasses. J. Chem. Technol. Biotechnol. 85(10), 1361-1367.

Patrascu, E., Rapeanu, G. and Hopulele, T. (2009) Current approaches to efficient biotechnological production of ethanol. Innovat. Rom. Food Biotechnol. 4, 1-11.

Pérez-Torrado, R., Gómez-Pastor, R., Larsson, C. and Matallana, E. (2009) Fermentative capacity of dry 
active wine yeast requires a specific oxidative stress response during industrial biomass growth. Appl. Microbiol. Biotechnol. 81(5), 951-960.

Phisalaphong, M., Srirattana, N. and Tanthapanichakoon, W. (2006) Mathematical modeling to investigate temperature effect on kinetic parameters of ethanol fermentation. Biochem. Eng. J. 28, 36-43.

Piskur, J., Rozpedowska, E., Polakova, S., Merico, A. and Compagno, C. (2006) How did Saccharomyces evolve to become a good brewer? Trends Genet. 22, 183-186.

Rasmey, A.M., Hassan, H.H., Aboseidah, A.A. and Abdul-Wahid, O.A. (2017) Chemical pretreatment and saccharification of sugarcane bagasse for bioethanol fermentation by Saccharomyces cerevisiae Y17 -KP096551. Basic Res. J. Microbiol. 4(1), 1-11.

Razmovski, R. and Vucurovi, V. (2011) Ethanol production from ' sugar beet molasses by $S$. cerevisiae entrapped in an alginate maize stem ground tissue matrix. Enzym Microbiol. Tech. 48 (5), 378-385.

Reddy, L.V.A. and Reddy, O.V.S. (2006) Rapid and enhanced production of ethanol in very high gravity (VHG) sugar fermentation by Saccharomyces cerevisiae: Role of finger millet (Eleusinecoracana L.) flour. Process Biotechnol. 41, 726-729.

Reed, G. (2001) Production of fermentation alcohol as a fuel source. In: "Prescott \& Dunn's Industrial Microbiology", Reed, G. (Ed.), pp.853-859, $4^{\text {th }} \mathrm{ed}$. AVI Publishing.

Reed, G. and Nagodawithana, T.W. (1988) Technology of yeast usage in winemaking. Am. J. Enol. Vitic. 39(1), 83-90.

Sadik, M.W. and Halema, A.A. (2014) Production of ethanol from molasses and whey permeate using yeasts and bacterial strains. Int. J. Curr. Microbiol. App. Sci. 3(3), 804-818.

Saitou, N. and Nei, M. (1987) The neighbor-joining method: A new method for reconstructing phylogenetic trees. Mol. Biol. Evol. 4(4), 406-425.

Sedha, R.K., Verma, G. and Gupta (2000) Ethanol fermentation from molasses using cell recycling of S. cerevisiae. J. Ferment. Technol. 62(5), 345-352.
Shashank, I. (1994) Effect of pretreatment of molasses and post treatment of fermented broth in industrial production of ethanol. App. Microbiol. Biotechnol. 45-46 (1), 181-187.

Silalertruksa, T. and Gheewala, S.H. (2010) Security of feedstocks supply for future bioethanol production in Thailand. Energy Policy, 38, 7426-7486.

Sunggyu, L. and Shah, Y.T. (2012) "Biofuels and Bioenergy: Process and Technologies". CRC Press Taylor \& Francis Group, pp. 341.

Suryawati, L., Wilkins, M.R., Bellmer, D.D., Huhnke, R.L., Maness, N.O., Banat, I.M. (2008) Simultaneous saccharification and fermentation of Kanlowswitch grass pretreated by hydro thermolysis using Kluyveromyces marxianus IMB4. Biotechnol. Bioeng. 101(5), 894-902.

Thompson, J.D., Gibson, T.J., Plewniak, F., Jeanmougin, F. and Higgins, D.G. (1997) The CLUSTAL_X windows interface: Flexible strategies for multiple sequence alignment aided by quality analysis tools. Nucleic Acids Res. 25, 4876-4882.

Wickerham, L.J. (1951) Taxonomy of yeasts, Tech. Bull. U.S. Department of Agriculture, 1029, 1-55.

Yadav, B.S., Sheoran, A., Rani, U. and Singh, D. (1997) High ethanol productivity in an immobilized cell reactor. Indian J. Microbiol. 37, 65-67.

Zayed, G.Z.A. and Foley, J. (1987) The influence of fermentation conditions on ethanol yields from sugar beet molasses and fodder beet juice using Saccharomyces cerevisiae strains. Irish J. Food Sci. Technol. 11, 119-133.

Zohri, A.A. and Mostafa, E. (2000) Ethanol production from dates in Saudi Arabia on industrial scale. Microbiology, 28(2), 76-81.

Zohri, A.A., Ramadan, A.M., El-Tabakh, M.M. and El-Tantawy, K. (2012) Studies on optimization conditions for alcoholic fermentation process of delta beet molasses. International Conference on: New Role for the World Sugar Economy in a Changed Political and Economic Environment. Aswan, Egypt.

(Received 11/10/2017; accepted 15/7/2018) 


\title{
Saccharomyces) تحسين انتاجية الايثانول الحيوى بواسطة خميرة سكاروميسيس سبرفيسيا (cerevisiae رقم Y17 من مولاس قصب السكر

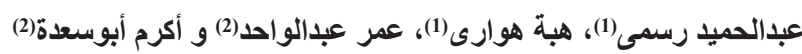

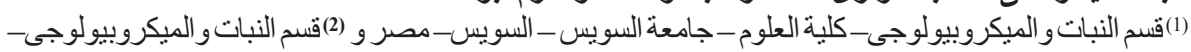 كلية العلوم - جامعة قناة السويس - الاسماعيلية_ -مصرم.
}

\begin{abstract}
تهدف هذه الدر اسة إلى محاولة استخدام المخلفات الصناعية الزر اعية مثل قصب السكر ودبس البنجر لإنتاج

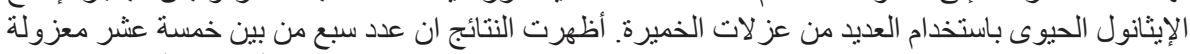

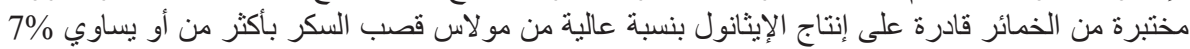

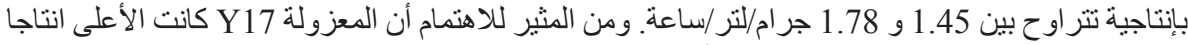

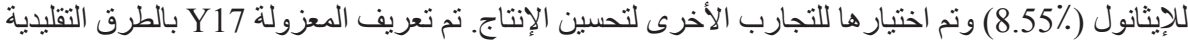

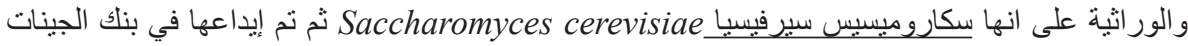

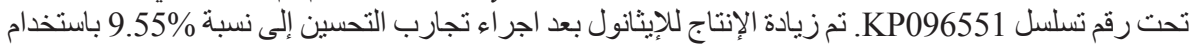

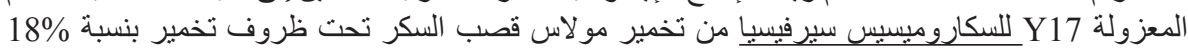

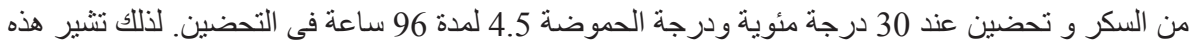

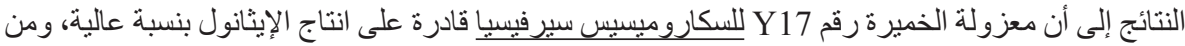

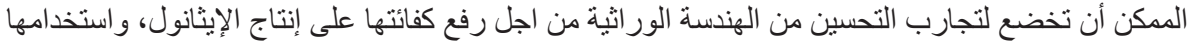

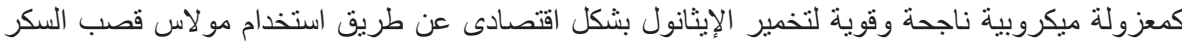
كمصدر متجدد ومنخفض التكلفة.
\end{abstract}

